\title{
DETEKSI PENYAKIT PADA DAUN TEMBAKAU DENGAN MENERAPKAN ALGORITMA ARTIFICIAL NEURAL NETWORK
}

\author{
Diana Laily Fithri \\ Dosen Fakultas Teknik, Program Studi Sistem Informasi \\ Universitas Muria Kudus \\ Email: dila_fitri@yahoo.com
}

\begin{abstract}
ABSTRAK
Artificial Neural Network ( ANN ) Perceptron merupakan salah satu dari metode AI yang telah terbukti cukup handal untuk digunakan sebagai teknik pengenalan atau pengindentifikasian.Tujuan dari dibuatnya penelitian ini adalah untuk menerapkan metode Jaringan Syaraf Tiruan atau Artificial Neural Network dengan algortima Perceptron dalam menentukan penyakit cacar daun dan bercak daun pada daun tembakau serta daun cengkeh, dimana sampel daun-daun tersebut dianalisis melalui kedelapan gejala atau ciri yang ditimbulkannya.Tahapan awal yang dilakukan yaitu mengumpulkan beberapa sampel daun tembakau dan daun cengkeh, baik yang terkena penyakit maupun tidak. Kemudian mengelompokkan gejala atau ciri khusus yang ditimbulkan pada setiap daunnya dari penyakit cacar daun dan bercak daun. Ciri penyakit yang positif terlihat pada masing-masing daun akan direpresentasikan dengan nilai bipolar [1, -1], dimana ciri tersebut akan digunakan sebagai nilai masukan pada tahap pelatihan (training) dan pengujian (testing) dalam metode ANN. Dari hasil pengujian terhadap sampel sebanyak 20 daun untuk tahap training dan 10 sampel daun untuk tahap testing, dengan perbandingan penyakit bercak daun dan cacar daun adalah 50 : 50, learning rate sebesar 0,7, lapisan masukan sebanyak 8 buah, dan 1 buah lapisan luaran, didapat bahwa metode ANN Perceptron memiliki persentase keberhasilan pengenalan penyakit sebesar $61 \%$ - 73\% untuk data non-learning, dan $100 \%$ untuk data learning pada kedua jenis daun tersebut.

Kata kunci : ANN Perceptron, bipolar, learning rate, cacar daun, bercak daun.
\end{abstract}

\section{ABSTRACT}

Artificial Neural Network (ANN) is one of the Perceptron AI methods that have been proven reliable enough to be used as an introduction or a technique made pengindentifikasian.Tujuan of scientific writing is to apply the methods of Artificial Neural Networks or Artificial Neural Network with Perceptron algorithm in determining disease smallpox leaves and leaf spot on tobacco leaf and clove leaf, which leaves the sample is analyzed through eighth symptoms or traits that made the initial ditimbulkannya.Tahapan collected some samples of tobacco leaf and leaf clovers, both affected by the disease or not. Then the group of symptoms or traits generated at each leaf of smallpox leaves and leaf spot. Positive disease traits seen in each leaf will be represented by the value of bipolar [1, -1], where the traits will be used as input values in the training phase (training) and testing (testing) in the ANN method. From the results of tests on a sample of 20 leaves for training phase and 10 leaf samples for testing phase, the ratio of leaf spot diseases and smallpox leaf is 50: 50, learning rate of 0.7, the input layer as many as 8 pieces, and 1 output layer, found that the ANN method Perceptron has a percentage of the successful introduction of the disease by $61 \%-73 \%$ for non-learning the data, and $100 \%$ for the learning of data on both types of leaves.

Keywords: ANN Perceptron, bipolar, learning rate, smallpox leaves, leaf spot.

\section{PENDAHULUAN}

Kebutuhan akan piranti pengenal / pendeteksi yang handal sangat dibutuhkan. Pengembangan teknologi pengenalan yang berupa kecerdasan buatan (Artificial Intelligence) menjadi sangat penting dan membantu karena selain mempermudah, juga mempercepat pekerjaan manusia. Salah satu ilmu yang mendukung teknologi tersebut adalah Artificial Neural Network (Jaringan Syaraf Tiruan), dimana dalam sepuluh tahun terakhir pengaplikasiannya telah banyak dikembangkan di berbagai bidang dalam kehidupan manusia. Seperti contoh Aplikasi Adaptive Inteligent System adalah Sistem mengenali Panas, Hangat, dan Dingin Menggunakan Jaringan Syaraf Tiruan dan Himpunan Fuzzy begitu juga seperti Adaptive Noise Canceling yang menggunakan jaringan syaraf tiruan untuk membersihkan gangguan pada telephone (dikenal dengan echo) dan mengurangi kesalahan tranmisi modem dll. 
Perkembangan perangkat lunak dan perangkat keras yang begitu pesat di era modern ini, ilmu kecerdasan buatan ini juga tidak ingin ketinggalan dengan perangkat-perangkat tersebut meskipun belum menyebar secara luas dalam masyarakat tapi bidang kecerdasan buatan ini sudah menunjukkan hasilnya terlihat seperti sedikit contoh yang disebutkan sebelumnya yang merupakan hasil dari kecerdasan buatan yang telah diaplikasikan dalam kehidupan nyata. Kecerdasan buatan ini juga bisa digunakan untuk menentukan pola maupun pendektisian dan pengenalan terhadap penyakit yang menyerang berbagai tanaman terutama daunnya. Daun merupakan bagian dari tumbuhan yang bisa diketahui secara langsung dengan melihat fisik daun tersebut apakah tanaman ini atau daun ini berpenyakit atau tidak berpenyakit yaitu dengan menggunakan kecerdasan buatan atau Artificial Intelligence meteode perceptron. Metode perceptron ini adalah metode yang cukup handal dalam jaringan syaraf tiruan yaitu metode mengenali pola dengan baik, bisa dikatakan handal karena metode perceptron ini memiliki prosedur belajar yang dapat mengahasilkan bobot yang konvergen sehingga memungkinkan output yang didapat sesuai dengan target tiap input pola.

Metode perceptron ini yang akan digunakan untuk mengidentifikasi daun apakah terkena penyakit cacar daun atau bercak daun. Metode perceptron ini cukup ampuh untuk pengenalan gejala-gejala yang terlihat secara fisik di daun tembakau dan cengkeh dengan menggunakan pola kusus dan perhitungan matematis yang akan kita buat untuk proses sample dan testing. Metode ini nantinya yang akan kita pakai untuk mengenali atau mengidentifikasi penyakit daun berupa cacar daun dan bercak daun dari gejala fisik yang ditimbulkan oleh daun itu sendiri. Salah satu penerapan metode perceptron ini yaitu pengenalan penyakit daun pada tanaman tembakau dan tanaman cengkeh. Disini identifikasi kita tujukan pada bagian daun, seperti permukaan daun, warna daun, pola daun dll. Pemilihan daun tembakau dan daun cengkeh disini didasarkan atas manfaat yang dihasilkan oleh kedua daun tersebut yang bermanfaat untuk kebutuhan manusia itu sendiri beberapa diantaranya seperti daun tembakau untuk pembuatan rokok, kemudian yang terbaru ini yaitu tembakau mempunyai kasiat sebagai reaktor protein anti kangker. Selanjutnya yaitu daun cengkeh mempunyai manfaat banyak manfaat diantaranya adalah untuk penyedap makanan dibidang kesehatan untuk pengobatan seperti mual, muntah-muntah, melancarkan pencernaan, kolera, asma, sakit gigi dll.

Pemilihan kedua daun tersebut didasarkan pada manfaat yang dimilikinya. Daun ini sangat bermanfaat untuk kehidupan manusia dan merupakan hal yang tidak rahasia lagi bagi umum mengenai manfaat kedua daun tersebut yaitu daun tembakau dan cengkeh. Disini dengan adanya manfaat yang besar dari kedua daun tersebut maka dengan menggunakan metode perceptron ini diharapkan bisa menjadi referensi untuk mengetahui cara menentukan apakah kedua daun tersebut terkena penyakit bercak daun dan cacar daun atau tidak sama sekali.

\section{TINJAUAN PUSTKA}

\subsection{Jaringan Syaraf Tiruan}

Jaringan Syaraf Tiruan (JST) didefinisikan sebagai suatu system pemrosesan informasi yang mempunya karakteristik menyerupai jaringan syaraf manusia. JST tercipta sebagai suatu generalisasi model matematis dari pemahaman manusia (Andry, 2004)

Ada beberapa tipe jaringan syaraf, namun demikian hampir semuanya memiliki komponen-komponen yang sama. Seperti halnya otak manusia, JST juga terdiri dari beberapa neuron dan terdapat penghubung antara neuron-neuron tersebut (Arif H, 2006). Gambar 1 di bawah ini menunjukkan struktur neuron jaringan syaraf tiruan.

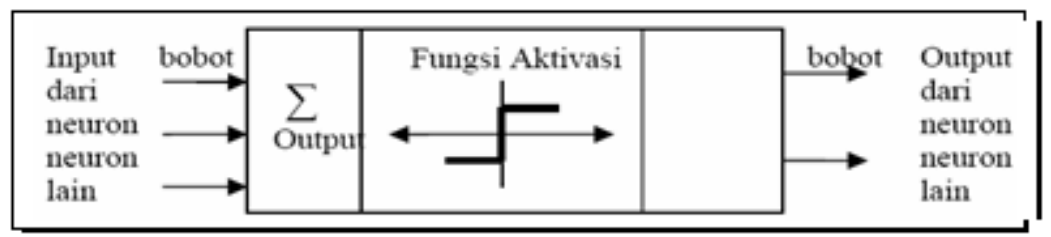

Gambar 1. Struktur Neuron Jaringan Syaraf Tiruan

(Sumber Arif H, Jaringan syaraf tiruan dan aplikasi)

Gambar di atas menunjukkan bahwa neuron buatan sebenarnya mirip dengan sel neuron biologis. Neuron-neuron bekerja dengan cara yang sama pula dengan sel neuron biologis.

Jaringan Syaraf Tiruan yang telah dan sedang dikembangkan merupakan pemodelan matematika dari jaringan syaraf biologis, berdasarkan asumsi :

1. Pemrosesan informasi terjadi pada banyak elemen pemroses sederhana yang disebut neuron

2. Sinyal dilewatkan antar neuron yang membentuk jaringan neuron 
3. Setiap elemen pada jaringan neuron memiliki 1 (satu) pembobot. Sinyal yang dikirimkan ke lapisan neuron berikutnya adalah informasi dikalikan dengan pembobot yang bersesuaian.

4. Tiap-tiap neuron mengerjakan fungsi aktivasi untuk mendapatkan hasil output masing-masing.

JST di dalam penggunaannya dapat terbagi menjadi bermacam arsitektur, dan suatu jaringan syaraf sederhana dalam Gambar 2 berikut ini :

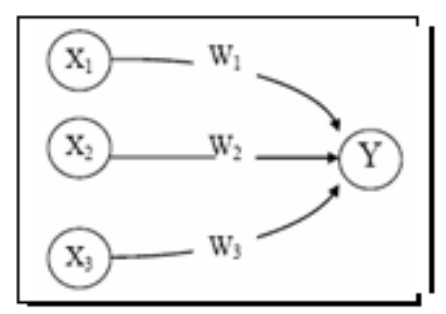

Gambar 2. Jaringan Syaraf Tiruan Sederhana dengan Satu Output [3]

(Sumber Ary N, Satryo PH, Wahyono. Pengenalan Huruf Berbasis Jaringan Syaraf Tiruan Menggunakan Algoritma Perceptron)

Pada gambar di atas, neuron $\mathrm{Y}$ menerima input dari neuron $\mathrm{X}_{1}, \mathrm{X}_{2}$, dan $\mathrm{X}_{3}$ serta $\mathrm{W}_{1}, \mathrm{~W}_{2}$, dan $\mathrm{W}_{3}$ merupakan pembobot antar koneksi dari $\mathrm{X}_{1}, \mathrm{X}_{2}, \mathrm{X}_{3}$ terhadap neuron Y. Jaringan input $\mathrm{y}$ _in pada neuron $\mathrm{Y}$ merupakan penjumlahan dari perkalian neuron-neuron input dengan masing-masing pembobot yang bersesuaian, dimana :

$$
\mathrm{y}_{-} \text {in }=\sum \mathrm{Xi} \cdot \mathrm{Wi}
$$

lalu y_in diberikan fungsi aktivasi untuk menghasilkan neuron Y.

Pada JST, belajar adalah proses pembentukan konfigurasi harga-harga bobot dari jaringan. Proses ini bertujuan agar input-input yang diberikan padanya akan direspon melalui bobot-bobot tersebut sehingga menghasilkan output yang sesuai atau mendekati dengan target.

\subsection{Bercak dan Cacar Daun Tembakau dan Daun Cengkeh}

Daun cengkeh dan daun tembakau merupakan dua jenis daun yang sering dimanfaatkan oleh masyarakat, baik itu untuk dikonsumsi langsung maupun diolah lebih lanjut untuk menghasilkan suatu produk.

Kedua jenis daun ini banyak sekali memberikan manfaat. Pada daun tembakau contohnnya, digunakan sebagai bahan dasar dalam pembuatan rokok dan dapat memproduksi protein untuk melawan sel-sel kanker . Sedangkan pada daun cengkeh, biasa dimanfaatkan oleh masyarakat sebagai tanaman obat dalam menyembuhkan penyakit seperti sakit gigi, mual, muntah, kembung, dan lain-lain (Asian Brain, 2010). Dikarenakan memiliki berbagai manfaat itulah, kedua jenis daun tersebut banyak diproduksi.

Namun dalam produksinya, seringkali kedua jenis daun tersebut tidak memberikan kualitas yang baik pada saat pemilahan dari hasil penanaman para petani. Hal ini disebabkan daun-daun tersebut telah rusak akibat adanya jamur, bakteri atau virus dalam bentuk getah yang menghinggapi, sehingga membentuk suatu bercak dan gelembung dipermukaannya yang lama kelamaan merusak daun.

Hal ini didasarkan dari hasil penelitian yang dilakukan oleh seorang ilmuwan Jerman bernama Adolf Mayer terhadap daun tembakau, yang kemudian dikembangkan lagi penelitian tersebut oleh seorang ahli virus Amerika Serikat bernama Wendell Stanley, yang kemudian menyimpulkan bahwa bercak dan gelembunggelembung yang terjadi pada permukaan daun tembakau disebabkan oleh organisme patogen bernama Tabacco Mosaic Virus (TMV).

\section{METODE PENELITIAN}

\subsection{Metode Pengumpulan Data}

Data yang dikumpulkan di dalam penulisan jurnal ini adalah berupa sekumpulan ciri-ciri atau gejala yang dapat dilihat oleh mata secara langsung pada daun cengkeh dan daun tembakau yang mengalami penyakit bercak dan cacar daun, dimana diambil berdasarkan hasil pengamatan dan penelusuran pustaka sebelumnya. Ciri-ciri atau gejala kedua penyakit daun tersebut dikelompokkan menjadi 8 jenis :

a. Gejala A : bercak merah kecoklatan

b. Gejala B : belang-belang 
c. Gejala $\mathrm{C}$ : berlubang

d. Gejala D : bercak putih

e. Gejala E : bercak coklat kehijauan

f. Gejala F : bintik hitam

g. Gejala $\mathrm{G}$ : gugur daun

h. Gejala $\mathrm{H}$ : bercak menggelembung

dimana untuk Gejala A, B, C, D, E, F merupakan gejala dari penyakit bercak daun, dan Gejala F, G, dan H adalah gejala dari penyakit cacar daun.

\subsection{Pengolahan data}

Data daun yang akan digunakan dalam proses JST, sebelumnya akan dikonversi ke dalam bentuk nilainilai bipolar [1, -1] dan biner [1,0], dengan memiliki komposisi perbandingan $50: 50$ terhadap jumlah daun dan penyakit dari kedua jenis daun tersebut.

Di bawah ini adalah tabel 1 yang menunjukkan data pelatihan dan pengujian yang akan digunakan pada proses berikutnya :

Tabel 1. Sampel Daun untuk Pelatihan

\begin{tabular}{llllllllll}
\hline Daun & Gejala & Gejala & Gejala & Gejala & Gejala & Gejala & Gejala & Gejala & Target \\
Ke- & A & B & C & D & E & F & G & H & \\
\hline 1 & + & + & + & + & - & + & + & - & 1 \\
2 & + & + & - & + & - & - & - & - & 1 \\
3 & + & - & + & - & - & - & - & - & 1 \\
4 & + & + & - & + & - & + & - & - & 1 \\
5 & - & - & + & + & - & - & - & + & 1 \\
6 & - & - & + & + & - & + & - & - & 1 \\
7 & - & + & - & - & + & + & - & - & 1 \\
8 & - & - & + & - & + & + & + & - & 1 \\
9 & - & - & - & - & + & + & + & - & 1 \\
10 & - & - & - & - & - & + & - & - & 1 \\
11 & - & - & - & - & - & - & - & + & -1 \\
12 & - & - & - & - & - & - & - & + & -1 \\
13 & - & - & - & - & - & + & + & + & -1 \\
14 & - & - & - & - & - & + & + & - & -1 \\
15 & - & - & - & - & - & + & + & - & -1 \\
16 & - & - & - & - & - & + & - & + & -1 \\
17 & - & - & - & - & - & + & - & - & -1 \\
18 & - & - & - & - & - & + & - & - & -1 \\
19 & - & - & - & - & - & - & - & + & -1 \\
20 & - & - & - & - & - & - & - & + & -1 \\
\hline
\end{tabular}

Dengan keterangan :

Target / Output :

$$
\begin{aligned}
& \text { Bercak Daun = "1" } \\
& \text { Cacar Daun = "-1" } \\
& \text { Input : } \\
& \text { Ada Gejala }(+)=" 1 " \\
& \text { Tidak Ada Gejala }(-)=\text { " } 0 "
\end{aligned}
$$


Sedangkan untuk data pengujian, dapat dilihat melalui tabel 2 di bawah ini :

Tabel 2. Sampel Daun untuk Pengujian

\begin{tabular}{llllllllll}
\hline Daun & Gejala & Gejala & Gejala & Gejala & Gejala & Gejala & Gejala & Gejala & Output \\
Ke- & A & B & C & D & E & F & G & H & \\
\hline 1 & + & + & - & - & - & - & + & - & \\
2 & - & + & - & + & - & + & - & - \\
3 & - & + & - & + & - & - & + & - \\
4 & - & - & + & - & + & - & - & - \\
5 & + & - & + & - & - & + & - & - \\
6 & - & - & - & - & - & + & + & - \\
7 & - & - & - & - & - & + & - & + \\
8 & - & - & - & - & - & + & - & + \\
9 & - & - & - & - & - & - & + & + \\
10 & - & - & - & - & - & - & + & + & \\
\hline
\end{tabular}

Hasil dari pengujian pada tabel 2 akan memiliki persentase keberhasilan $100 \%$ jika output yang dihasilkan memiliki urutan 5 daun pertama adalah "Bercak Daun" dan 5 daun kedua adalah "Cacar Daun".

\subsection{Alur jaringan syaraf tiruan Perceptron}

Alur jaringan syaraf tiruan Perceptron untuk deteksi penyakit pada daun tembakau dengan menerapkan Algoritma artificial network dapat dilihat di gambar 3 yang ada di bawah ini.

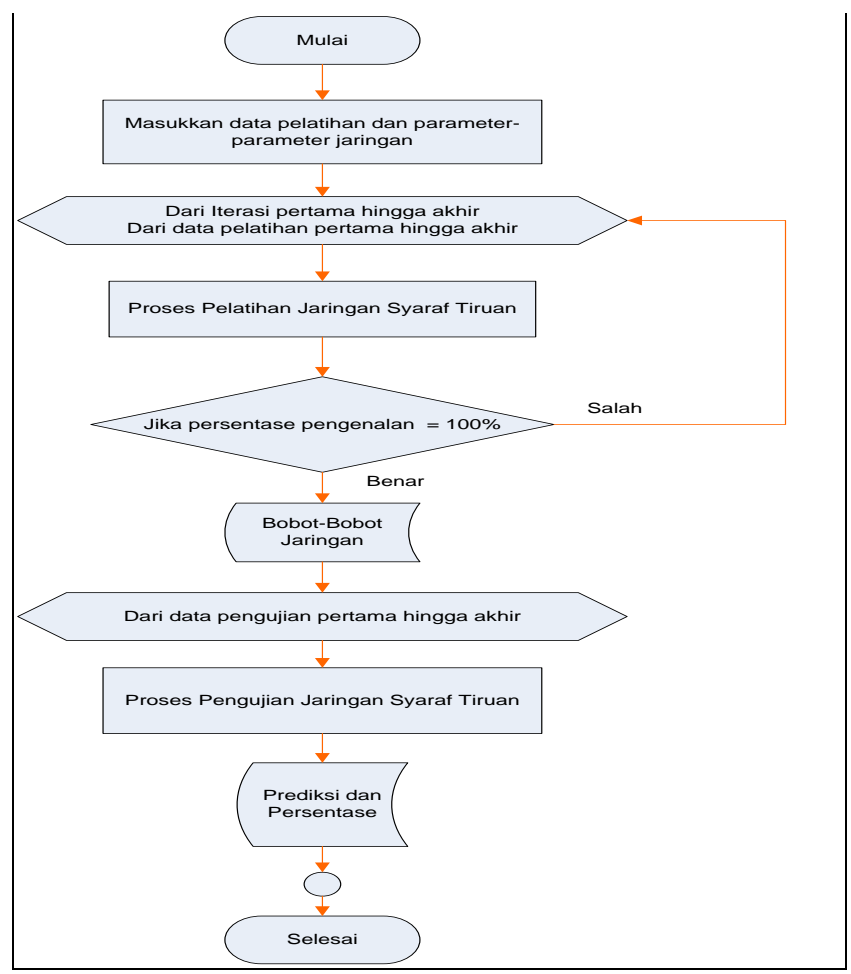

Gambar 3 : Alur deteksi penentuan penyakit

\section{HASIL PENELITIAN}

Nilai-nilai parameter jaringan yang ditetapkan yaitu :
a. Jumlah Sampel $=20$ (Pelatihan), 10 (Pengujian)
b. Unit input
$=8$ unit
c. Unit output
$=1$ unit
d. Iterasi
$=1000$ epoch
e. Threshold
$=0$
f. Kecepatan Belajar
$=0,1 \mathrm{~s} / \mathrm{d} 1,0$
g. Bobot Awal
$=-1.0 \mathrm{~s} / \mathrm{d} 1.0$ (acak) 
1. Tahap Pelatihan JST (Training)

Pada tahap ini, data input yang berupa sekumpulan gejala dari ke-20 daun tersebut akan diproses bersamaan dengan pembobot awal, yang kemudian akan menghasikan persentase pelatihan dan nilai bobot akhir untuk digunakan dalam tahap pengujian. Proses training jaringan syaraf tiruan dapat dilihat dalam gambar 4 yang ada di bawah ini.

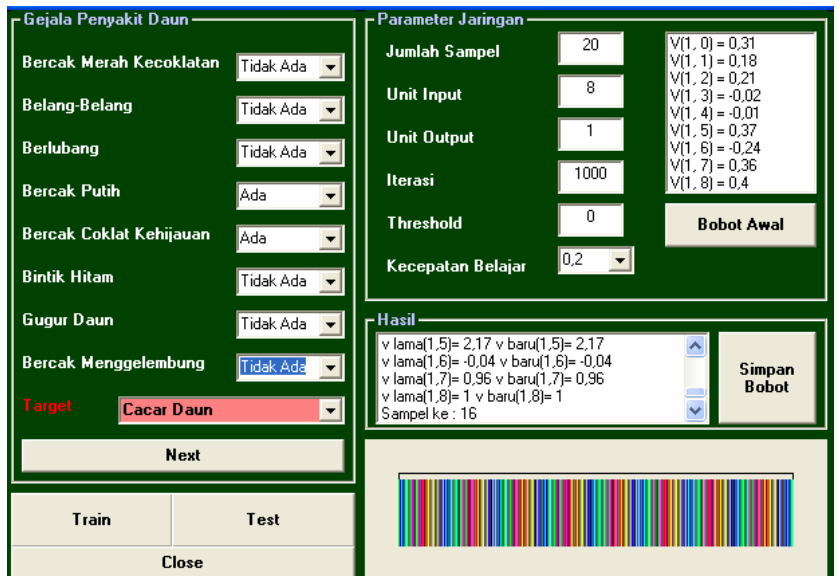

Gambar 4 : Proses training jaringan syaraf tiruan

Dari hasil pelatihan jaringan tersebut, kemudian didapat bobot-bobot akhir yaitu $\{-0.29,0.78,0.81,1.78$, $1.19,2.17,0.36,0.96,1\}$ dari persentase pengenalan sebesar 100\%. Bobot-bobot inilah yang kemudian digunakan dalam proses pengujian.

2. Tahap Pengujian JST (Testing)

Pada tahap ini, akan dilakukan proses pengujian akhir dari ke-10 data daun yang belum diketahui output atau targetnya dengan mempergunakan hasil bobot dari pelatihan sebelumnya. Gambar 5 di bawah ini menunjukkan proses testing JST untuk mendeteksi penyakit pada daun tembakau.

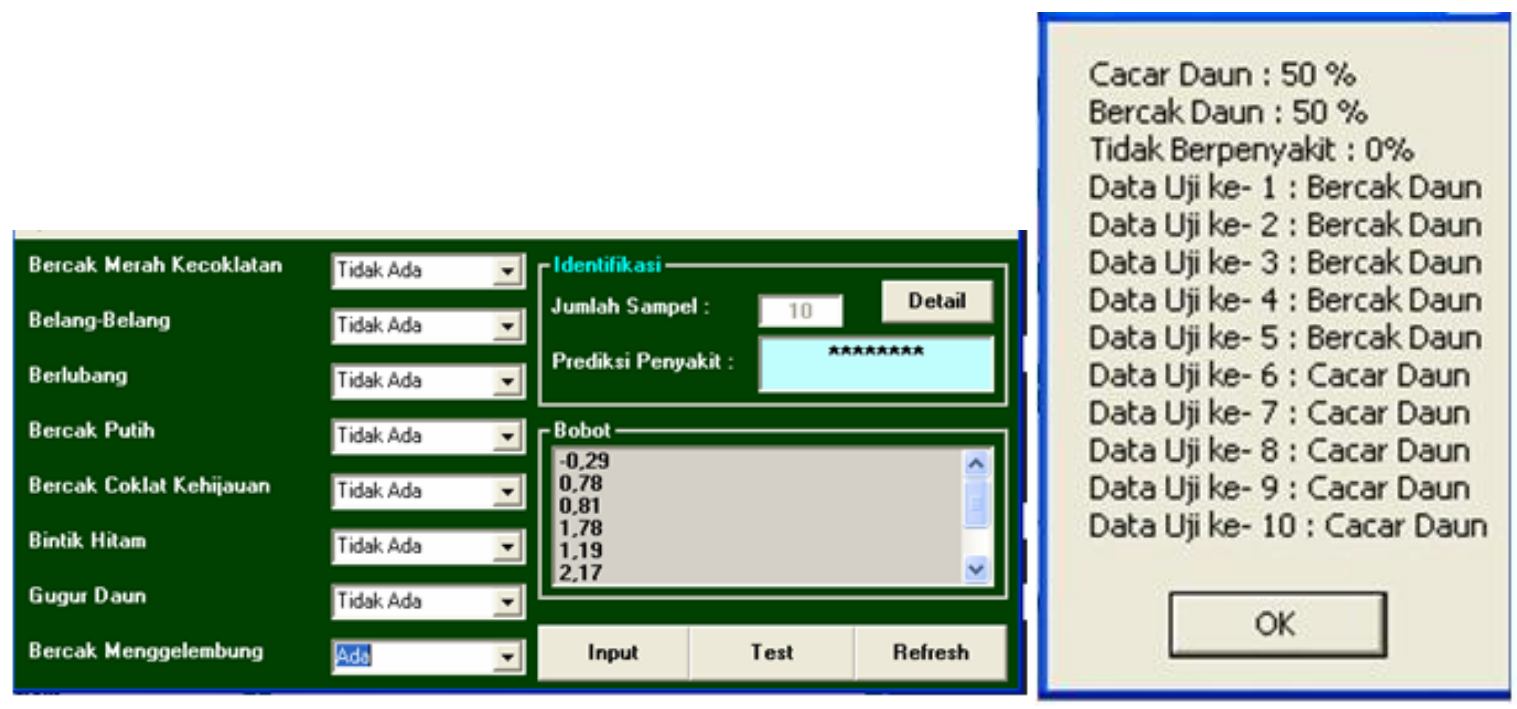

Gambar 5 : Proses testing JST

Dari gambar di atas, dapat dilihat bahwa proses pengujian telah menghasilkan prediksi dengan tepat, yaitu 5 urutan pertama adalah bercak daun dan 5 urutan kedua adalah cacar daun. Dengan kata lain pengujian secara urutan yang sama dengan urutan pelatihan memiliki keberhasilan $100 \%$ 
Namun jika dilakukan pengujian dengan beberapa data ( 3 daun) yang hanya berpenyakit bercak daun, hasil pengujiannya masih terdapat kesalahan sekitar 33\%. Hal ini dikarenakan dari 3 data bercak daun yang diuji, 1 diprediksi cacar daun, seperti terlihat pada gambar 6 yang ada dalam tampilan dibawah ini :

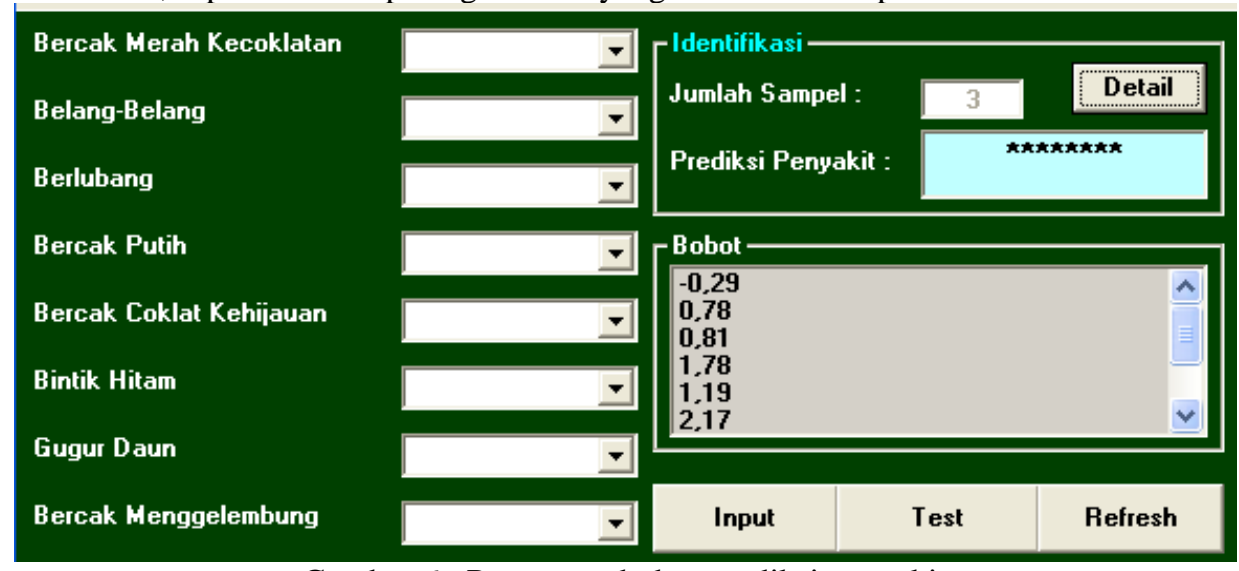

Gambar 6 : Penentuan bobot prediksi penyakit

\section{PEMBAHASAN}

Metode Perceptron merupakan salah satu dari metode Jaringan Syaraf Tiruan yang dapat digunakan untuk membuat sebuah sistem pengenalan dengan tingkat keberhasilan yang cukup baik. Hal ini dikarenakan lebih dari $50 \%$ data yang diuji dapat diprediksi penyakitnya dengan tepat.

Penggunaan nilai threshold sebesar 0 , learning rate sebesar 0.2 , iterasi sebanyak 1000 epoch, unit input sebanyak 8 buah, dan 1 buah unit output menunjukkan bahwa sistem telah cukup berhasil memprediksi data uji non-learning.

Pengujian dengan perbandingan penggunaan data sebesar $50: 50$ dari data daun berpenyakit bercak dan cacar daun, memiliki persentase keberhasilan sebesar $100 \%$. Sedangkan untuk perbandingan penggunaan data yang tidak imbang, yakni sebesar 100 : 0, sistem memiliki tingkat keberhasilan sebesar $66 \%$ dan kegagalan sebesar 33\%.

\section{KESIMPULAN}

Metode Artificial network merupakan metode untuk menentukan prediksi penyakit pada daun tembakau, yaitu penyakit bercak daun dan cacar daun dengan hasil pengujian tingkat kesalahan sebesar 33\% dengan menggunakan data training dan data testing. Pengujian dengan perbandingan penggunaan data sebesar $50: 50$ dari data daun berpenyakit bercak dan cacar daun, memiliki persentase keberhasilan sebesar $100 \%$. Sedangkan untuk perbandingan penggunaan data yang tidak imbang, yakni sebesar $100: 0$, sistem memiliki tingkat keberhasilan sebesar $66 \%$ dan kegagalan sebesar $33 \%$.

\section{DAFTAR PUSTAKA}

[1] Andry H. 2004. Studi Kasus Mengenai Aplikasi Multilayer Perceptron Neural Network Pada Sistem Pendeteksi Gangguan (IDS) Berdasarkan Anomali Suatu Jaringan. Bandung : Institut Teknologi Bandung.

[2] Arif H. 2006. Jaringan Syaraf Tiruan Teori dan Aplikasi. Yogyakarta : Penerbit ANDI

[3] Ary N, Satryo PH, Wahyono. Pengenalan Huruf Berbasis Jaringan Syaraf Tiruan Menggunakan Algoritma Perceptron. Http : //www.scrib.com/doc/13826849/pengenalan-huruf-berbasis-jaringan-syaraf-tiruanmenggunakan-algoritma-perceptron. Yogyakarta : Universitas Gadjah Mada

[4] Benyamin K, Renny I R. Pengembangan Sistem Pengenal Objek 3 Dimensi Menggunakan Sistem Jaringan Syaraf Tiruan dengan Lapisan Tersembunyi Berbentuk Silinder. Jurnal Ilmu Komputer dan TI

[5] Wim P, Yulian P. 2007. De Perceptron Aplikasi Market Basket Analysis Berbasis Web Menggunakan Perceptron. Yogyakarta : Universitas Gadjah Mada

[6] AsianBrain.com. Cengkeh dan Manfaatnya. http://www.anneahira.com/tanaman-obat/cengkeh.htm. [diakses Mei 2010]

[7] http://www.akademik.unsri.ac.id/download/journal/files/bai.journal/a hidir_sastraatmadja.pdf. Departemen Ilmu Hama dan Penyakit Tumbuhan : Institut Pertanian Bogor.

[8] Erwin. Bercak Daun si Perusaka Kualitas Cerutu. http://www.tanindo.com/abdi16/hal2901.htm. [diakses Mei 2010] 
[9] Mahmud, Zainal. Teknologi Unggulan Tanaman Cengkeh (Booklet Cengkeh). http://balittri.litbang.deptan.go.id/database/unggulan/bookletcengkeh.pdf. [diakses Juni 2010]

[10] Manfaat Tembakau Sebagai Reaktor Protein Anti Kanker. http://www.lipi.go.id/www.cgi?berita\&1221953354\&\&2008 ------------->>> Manfaat daun tembakau Manfaat Tembakau sebagai Reaktor Protein Anti Kangker. [diakses Juli 2010] 